\title{
Historyczno-teologiczne podstawy teorii wydarzenia liturgicznego zorientowanej trynitarnie
}

Artykuł, który niniejszym prezentuję, stanowi przyczynek do trynitarnie zorientowanej teologii liturgii, zbudowanej na pojęciu perychorezy trynitarnej. Ze względu na obfitość materiału badawczego cały argument podzielony zostanie na kilka części. Przedmiotem niniejszego artykułu - i jednocześnie pierwszej części całości wywodu - są historyczno-teologiczne podstawy rozumienia wydarzenia liturgicznego jako wydarzenia trynitarnego. Zostanie tu przedstawiona analiza formalnych wymiarów teologii liturgii w kluczu trynitarnym. Idzie tu nade wszystko o przedstawienie zarysu rozumienia liturgii jako rzeczywistości trynitarnej w teologicznej tradycji Kościoła. Analiza taka pozwoli na wyartykułowanie genetycznego związku pomiędzy liturgią a wiarą trynitarną. Ten zaś będzie stanowił punkt wyjścia do dalszych analiz. Część druga poświęcona będzie pojęciu perychorezy trynitarnej w perspektywie użycia tego pojęcia do teologicznego opisu liturgii. Część trzecia stanowić będzie analizę możliwości wykorzystania pojęcia perychorezy do opisu istoty liturgicznego działania oraz liturgii jako działania w perspektywie wypracowania z wnętrza liturgii teologicznej teorii podmiotu działającego. Zadaniem czwartej części będzie weryfikacja tezy o liturgicznym charakterze wewnętrznego życia Boga (J. Corbon).

\section{Liturgiczna geneza teologii chrześcijańskiej}

Wszelka refleksja teologiczna nad fenomenem liturgii musi być de facto konstatacją źródłowego i genetycznego związku pomiędzy powstaniem 
wczesnej wspólnoty i jej teologii a pra-celebracją liturgiczną ${ }^{1}$. Jest dzisiaj faktem niezaprzeczalnym, iż pierwotnym fenomenem chrześcijańskim jest kult liturgiczny powstały we względnej, przetransponowanej ciągłości względem kultu Izraela ${ }^{2}$. Warto zwrócić uwagę, iż w procesie tworzenia się kanonu jednym $\mathrm{z}$ istotnych argumentów kanoniczności danego tekstu był argument liturgiczny (użycie podczas liturgii) ${ }^{3}$. Zanim jeszcze zostały spisane księgi stanowiące dziś kanon Nowego Testamentu, pierwsi chrześcijanie celebrowali liturgię, w której obchodzili kultyczną pamiątkę śmierci i zmartwychwstania Chrystusa. Pamiątka ta była zarówno wyrazem ich żywej pamięci i próbą uzewnętrznienia podstawowych wektorów ich żywego doświadczenia Jezusa przed- i popaschalnego, jak i miejscem ich refleksji nad owym doświadczeniem podstawowym. Stanowi ona zatem - owa liturgiczna pamiątka - całkiem nowe jakościowo doświadczenie ${ }^{4}$ i przeżycie żywej obecności Pana, który „był umarły, a oto jest żyjący na wieki wieków" (Ap 1, 18).

${ }^{1}$ Por. J. F. Nielen, Gebet und Gottesdienst im Neuen Testament. Eine Studie zur biblischen Liturgie und Ethik, Freiburg 1937; D. Aune, Worship, Early Christian, [w:] The Anchor Bible Dictionary, t. 6, New Haven-London 1992, 973-989; P. M. Bradshaw, The Search for the Origins of Christian Worship. Sources and Methods for the Study of Early Liturgy, Oxford 2002; J. Roloff, Der Gottesdienst im Urchristentum, [w:] Handbuch der Liturgik: Liturgiewissenschaft in Theologie und Praxis der Kirche, hrsg. von H.-Ch. Schmidt-Lauber, M. Meyer-Blanck, K.-H. Bieritz, Göttingen 2003, 45-71; G. Wainwright, Christian Worship. Scriptural Basis and Theological Frame, [w:] G. Wainwright, The Oxford History of Christian Worship, Oxford 2005, 1-31; M. E. Johnson, Apostolic Tradition, [w:] G. Wainwright, The Oxford History of Christian Worship, dz. cyt., 32-76; A. Fürst, Die Liturgie der Alten Kirche: Geschichte und Theologie, Paderborn 2008; V. A. Alikin, The Earliest History of the Christian Gathering. Origin, Development and Content of the Christian Gathering in the First to Third Centuries, Leiden 2010 (Vigiliae Christianae. Supplements, 102).

${ }^{2} \mathrm{G}$. Rouwhorst, Christlische Gottesdienst und der Gottesdienst Israels. Forschungsgeschiechte, historische Interaktionen und Theologie, [w:] Theologie des Gottesdienstes, hrsg. von M. Klöckener, A. A. Häussling, R. Messner, t. 2: Gottesdienst im Leben der Christen, Regensburg 2008, 491-573 (Gottesdienst der Kirche. Handbuch der Liturgiewissenschaft, 2).

${ }^{3}$ Ch. Theobald, Kanon der Heiligen Schrift. III. Systematisch-theologisch, [w:] Lexikon für Theologie und Kirche, t. 5, Freiburg im Breisgau 1960, 1183n; por. B. Metzger, The Canon of the New Testament: its Origin, Development and Significance, Oxford 1987, 251nn; A. Ziegenaus, Kanon. Von der Väterzeit bis zur Gegenwart, Freiburg-Basel-Wien 1990, 9-10 (Handbuch der Dogmengeschichte, I.3a).

${ }^{4}$ Próbą filozoficzno-teologicznego opisu tego doświadczenia i jego treściowej zawartości jest analiza zaproponowana przez J. L. Marion, Prolégomènes à la charité, Paris 2007. Marion ujmuje całe pierwotne, popaschalne doświadczenie Jezusa w perspekty- 
Zauważony fakt posiada transcendentne znaczenie dla określenia zarówno kształtu jak i podstawowej zawartości wszelkiej teologii liturgii. Stwierdza on bowiem, powtórzymy raz jeszcze, uprzedniość działania liturgiczno-kultycznego wobec refleksji teologicznej. W rzeczy samej owo działanie może być uznane za pierwotny kształt refleksji nad wydarzeniem Chrystusa, jest ono bowiem w swojej formie konkretnym wyznaniem wiary ${ }^{5}$. Mamy tu zatem do czynienia nie tyle z teologią dyskursywną, co z teologią celebrowaną, czy teologią pojętą jako celebracja. Z natury rzeczy taka postać teologii wiąże się bardziej z przeżywaniem prawdy niż z jej dyskursywnym opracowywaniem. Jednocześnie - co zasługuje na znaczącą uwagę - taka pierwotna forma teologii jako celebracji stanowi dynamiczny impuls dla prób przemyślenia zawartości treściowej wiary, która już została „przedujęta” w liturgicznej celebracji.

Pierwotna liturgia jest jako wydarzenie tym, co daje do myślenia. Wyraźne odwołanie do sławnej definicji symbolu P. Ricouera wydaje się tutaj jak najbardziej na miejscu (le symbole donne à penser) ${ }^{6}$. Wszak liturgia

wie pojęcia paruzji oznaczającej zarówno obecność jak i przybywanie. Jego zdaniem, jakościowa nowość doświadczenia popaschalnego apostołów charakteryzuje się oscylacją między obecnością i nieobecnością Jezusa. Należałoby tu mówić zasadniczo o nowej formie obecności, która wykracza poza dotychczasowe rozumienie obecności i nieobecności. Pozorna nieobecność, manifestująca się negatywnie niewidzialnością, staje się przestrzenią doświadczenia radykalnie nowego wymiaru obecności. Ta zaś związana jest ściśle z rzeczywistością sakramentalno-liturgiczną, która stanowi trzon kościelnej egzystencji.

${ }^{5}$ Por. M. Wiles, The Making of Christian Doctrine: a Study in the Principles of Early Doctrinal Development, Cambridge 1967, 62-93.

${ }^{6}$ Por. P. Ricoeur, Le symbole donne à penser, „Esprit” 27 (1959) nr 7-8, 60-76: „«Le symbole donne à penser»: cette sentence qui m'enchante dit deux choses; le symbole donne; je ne pose pas le sens c'est lui qui donne le sens; mais ce qu'il donne, c'est à penser, de quoi penser. A partir de la donation, la position. La sentence suggère donc à la fois que tout est déjà dit en énigme et pourtant qu'il faut toujours tout commencer et recommencer dans la dimension du penser. C'est cette articulation de la pensée donnée à elle-même au royaume des symboles et de la pensée posante et pensante que je voudrais surprendre et comprendre". Powyższy opis kładący nacisk na donację sensu, jaka dokonuje się poprzez symbol, stanowi dobrą podstawę opisu liturgii w kontekście działania symbolicznego. Przy czym owa symboliczność wcale nie musi i de facto nie oznacza wykluczenia realistycznego opisu wydarzenia sakramentalno-liturgicznego. Na taką realistyczną, osadzoną w głębi bytu interpretację symbolu wskazuje sam Ricoeur w dalszej części swojego eseju, kiedy pod koniec tekstu zauważa, że: „Pour faire bref, je dirai que le symbole donne à penser que le Cogito est à l'intérieur de l'être et non 
jest niczym innym jak pewnego rodzaju symbolem, językiem symbolicznym, w którym została odsłonięta, dana do przeżycia i egzystencjalnie zakomunikowana prawda zbawienia dokonanego w Chrystusie i Duchu. Właśnie ze względu na swoją symboliczną strukturę powstałą na styku języka (słowa) i gestu liturgia jest tym, co daje do myślenia, co pobudza myślenie, co wzywa do przemyślenia wiary. Przemyśleć wiarę oznacza zaś w tej liturgicznej perspektywie zasadniczo dwie rzeczywistości: przemyślenie tego, co stanowi fundament liturgicznego wydarzenia, czyli sam fakt zbawienia, jak i przemyślenie własnego, liturgicznego już doświadczenia owego zbawienia. Zauważona podwójność materii zadanej myśleniu przez liturgię (zarówno obiektywne factum, jak i osobiste jego doświadczenie w liturgii) stanowi radykalny punkt wyjścia wszelkiej teologii. Wszak teologia będzie już zawsze refleksją nad faktycznie podarowanym zbawieniem w perspektywie jego konkretnego doświadczenia w liturgii.

Liturgia pierwotna stanowi zatem o całej dynamice i specyfice chrześcijańskiej teologii w jej pierwotnej postaci. Jej pomnikami są pisma Nowego Testamentu ${ }^{7}$, które powinny być rozumiane wewnątrz ich liturgicznego źródła. Pisma te jednocześnie stanowią nieusuwalną podstawę wszelkiej dalszej refleksji teologicznej. „O teologii możemy myśleć - stwierdza F. Young - jako o żywej konwersacji wewnątrz Kościoła, która wyrasta z i prowadzi do konkretnych praktyk wiary: liturgii, modlitwy, akcji społecznej, rozeznawania i podejmowania decyzji" ${ }^{3}$. Zauważona tu dwubiegunowość związku liturgii i teologii przyznaje samej liturgii wybitnie teologiczny charakter.

Z praktycznego punktu widzenia cały opisany powyżej proces można by ująćschematycznie w następującej postaci甲: pierwotna liturgia, stanowiąc

l'inverse; la seconde naïveté serait donc aussi une seconde révolution copernicienne: l'être qui se pose dans le Cogito découvre que l'acte même par lequel il s'arrache à la totalité participe encore de l'être qui l'interpelle en chaque symbole".

${ }^{7}$ Stwierdzenie teologicznego charakteru kanonicznych pism wczesnochrześcijańskich jest tu istotnie ważne. To właśnie Nowy Testament jako zbiór ksiąg stanowi najpierwotniejszą postać chrześcijańskiej teologii. Zob. K. Vanhoozer, First Theology. God, Scripture \& Hermeneutics, Downers Grove, Illinois-Leicester, England 2002.

${ }^{8}$ F. Young, The Trinity and the New Testament, [w:] The Nature of New Testament Theology, ed. by Ch. Rowland, Ch. Tuckett, Oxford 2006, 287.

${ }^{9}$ Szczegółowe przedstawienie genezy kanonu można znależć w: R. E. Brown, R. F. Collins, Canonicity, [w:] R. E. Brown, J. A. Fitzmyer, R. E. Murphy, New Jerome Biblical 
uzewnętrznienie apostolskiej pamięci, jest słowno-gestualną celebracją, która z natury rzeczy zawiera elementy rozumienia samej celebracji w jej odniesieniu do rzeczywistości celebrowanej (Chrystus w swojej zbawczej tajemnicy). Jako taka stanowi ona początek refleksji dyskursywnej, której ostateczna forma została spisana i zamknięta w postaci określonego kanonu Nowego Testamentu. Następnie pisma, które stanowią ów kanon, są odczytywane podczas liturgii, stanowiąc rodzaj przewodnika po chrześcijańskim doświadczeniu Boga w Jezusie i Duchu Świętym. Istnieje zatem wyraźna więź pomiędzy powstaniem kanonu pism nowotestamentalnych, pierwotną refleksją teologiczną w jej chrystologicznej postaci ${ }^{10} \mathrm{i}$ liturgią. Fundamentem i spoiwem tego związku jest sama liturgia, owa - jakją nazywa Markschies za Assmannem - teologia implicite ${ }^{11}$.

\section{Liturgiczne źródła dogmatu trynitarnego}

Punktem wyjścia formułowania się trynitarnej wiary Kościoła jest doświadczeniowy ${ }^{12}$ depozyt objawienia Boga, jakie miało miejsce w Chrystusie i Duchu Świętym ${ }^{13}$. Jego adresatami byli wybrani przez

Commentary, Englewood 1990, 1034-1054.

${ }^{10}$ E. Dirscherl, ,... der mit dem Vater und dem Sohn angebetet und verherrlicht wird“. Die Bedeutung der Liturgie für die Rede vom Wort und Atem Gottes in der Trinitätstheologie, [w:] Liturgie und Trinität, hrsg. von B. Groen, B. Kranemann, Freiburg-Basel-Wien 2008, 59-60 (Quaestiones Disputatae, 229).

${ }^{11} \mathrm{Ch}$. Markschies, Kaiserzeitliche christliche Theologie und ihre Institutionen: Prolegomena zu einer Geschichte der antiken christlichen Theologie, Tübingen 2007, 137.

${ }^{12}$ Doświadczenie jako podstawę teologii opisuje wyczerpująco R. Schaeffler, Philosophische Einübung in die Theologie, t. 1: Zur Methode und zur theologischen Erkenntnislehre, Freiburg 2008 (Scientia Religio). Filozoficzne podstawy jego koncepcji doświadczenia zostały wyłożone w: Erfahrung als Dialog mit der Wirklichkeit. Eine Untersuchung zur Logik der Erfahrung, Freiburg 1995. Z punktu widzenia historycznego warto zapoznać się z pracami: H. Geybels, Cognitio Dei experimentalis. A Theological Genealogy of Christian Religious Experience, Leuven 2007 (Bibliotheca Ephemeridum Theologicarum Lovaniensium, 209) oraz P. Miquel, L'expérience spirituelle dans la tradition chrétienne, Paris 2000 (Théologie historique, 108). Pojęcie doświadczenia jest również podstawą biblijnej chrystologii E. Schillbeeckxa zaprezentowanej w trylogii:Jezus, het verhaal van een levende, Bloemendaal 1974; Gerechtigheid en liefde, genade en bevrijding, Bloemendaal 1977; Mensen als verhaal van God, Baarn 1989.

${ }^{13}$ Boskie odsłanianie siebie w Duchu Świętym posiada zasadniczo inną naturę niż objawienie w Chrystusie. Mówiąc o objawieniu w Duchu Świętym, mam na myśli 
Chrystusa apostołowie. To oni właśnie otrzymali od samego Pana misyjny nakaz. Spełnieniem tego nakazu jest pierwotna liturgia chrzcielna stanowiąca tygiel i rezerwuar przyszłych formuł trynitarnych explicite. Wiara trynitarna rodzi się w swojej postaci explicite właśnie z celebracji chrztu ${ }^{14}$ jako wydarzenia bazowego całego chrześcijaństwa.

Uwypuklenie takiej perspektywy posiada o tyle doniosłą wagę, o ile ujawnia liturgiczną uprzedniość prawdy celebrowanej przed prawdą wyznawaną. Późniejsza zasada lex orandi lex credendi est odnosić się będzie nie tylko do rzeczywistości konkretnej formy liturgicznej aktu i materii wiary, dla których wydarzenie liturgiczne jest normatywne. Zasada ta bowiem odsłania nade wszystko ge n e zę dogmatu: pochodzi on z liturgii. Prawda wiary, zanim staje się przedmiotem systematycznej refleksji, jest już uprzednio formą i treścią celebracji. Liturgia jest fundamentalnie Sitz im Leben całej teologii. Najstarsze fragmenty Nowego Testamentu posiadają wybitnie liturgiczną kompozycję i charakter. Słynne hymny chrystologiczne (np. Flp 2, 6-11; Kol 1, 15-20; Ef 1, 3-14) przeszczepione do corpus Paulinum z pierwotnej liturgii świadczą dobitnie o liturgicznej genezie pism nowotestamentalnych ${ }^{15}$ w ich chrystologicznej postaci ${ }^{16}$. Również sama Apokalipsa to interpretacja historii zaproponowana przez „zgromadzenie liturgiczne”, które

pierwszorzędnie heremenutyczną rolę świadectwa Ducha Świętego o Jezusie. Swoiste objawienie w Duchu Świętym dokonuje się w tajemnicy sakramentalnie i liturgicznie ukonstytuowanego Kościoła, który jest szczególnym dziełem Ducha Świętego. Na temat początków teologii trynitarnej z ducha rodzącej się chrystologii zob. F. Dünzl, Kleine Geschichte des trinitarischen Dogmas in der Alten Kirche, Freiburg-Basel-Wien 2006, 11-19; J. Wohlmuth, Trinität - Versuch eines Ansatzes, [w:] Monotheismus Israels und christischer Trinitätsglaube, hrsg. von M. Striet, Freiburg-Basel-Wien 2004, 42nn (Quaestiones Disputatae, 210).

${ }^{14}$ Szerzej na temat samego chrztu, jego teologii i celebracji por. J. B. Revel, Traité des sacrements, t. 1-2, Paris 2004-2005 (Théologies).

${ }^{15} \mathrm{H}$. Langkammer, Hymny chrystologiczne Nowego Testamentu. Najstarszy obraz Chrystusa, Katowice 1976; por. R. P. Martin, Some Reflections on New Testament Hymns, [w:] Christ the Lord. Studies in Christology Presented to Donald Guthrie, ed. by H. H. Rowdon, Leicester 1982, 37-49; G. Segalla, La cristologia del Nuevo Testamento, Brescia 1985, 89-95.

${ }^{16}$ M. Hengel, Hymnus und Christologie, [w:] tenże, Studien zur Christologie. Kleine Schriften, t. 4, Tübingen 2006, 185-204 (Wissenschaftlische Untersuchungen zum Neuen Testament, 201); tenże, Das Christuslied im frühesten Gottesdienst, [w:] tenże, Studien zur Christologie, dz. cyt., 205-258. 
stanowi podstawowy wymiar ontologii fundamentalnej Kościoła i jej konkretne odsłonięcie ${ }^{17}$. Wspomnijmy również formuły epistolarnych pozdrowień (np. 2 Kor 13, 13), które w swojej formie posiadają wybitnie liturgiczny charakter ${ }^{18}$.

Intuicje takie potwierdza najnowsza debata o wczesnej liturgii i jej wymiarze doktrynalnym ${ }^{19}$. Jej protagonistami są Hurtado ${ }^{20}$, Hengel $^{21}$ i Bauckham ${ }^{22}$. Wszyscy wymienieni autorzy zgadzają się co do faktu związku pierwotnej liturgii i doktryny. Związek ten bądź jest genetyczny (doktryna powstaje z wydarzenia celebracji liturgicznej), bądź jest performatywny (liturgia odsłania, prezentuje doktrynalną zawartość wiary chrześcijańskiej). Oczywiste wydaje się, że oba procesy zachodziły w liturgii jednocześnie: tworzyła ona i odsłaniała pierwotny kształt i zawartość doktryny wiary, szczególnie w jej chrystologicznym wymiarze. To właśnie dzięki pierwotnej liturgii dokonała się inkluzja Chrystusa w przestrzeń kultyczną. Inkluzja ta stanowi kamień węgielny i potwierdzenie przekonania o boskiej naturze Jezusa Chrystusa (divine identity - identyfikacja Jezusa z Bogiem Izraela) ${ }^{23}$. Tak oto geneza trynitarnego (pierwotnie binitarnego) wyznania wiary jest ściśle liturgiczna. Świadkiem owej genezy są pisma Nowego Testamentu.

${ }^{17}$ U. Vanni, Apocalipsis. Una asamblea litúrgica interpreta la historia, Estalla 2001, 18.

${ }^{18}$ F. Courth, Trinität. In der Schrift und Patristik, Freiburg-Basel-Wien 1988, 29-30 (Handbuch der Dogmengeschichte, 2.1a); A. Hamman, Die Trinität in der Liturgie und im christlischen Leben, Einsiedeln 1967, 132-138 (Mysterium Salutis, 2).

${ }^{19} \mathrm{Na}$ temat debaty zob. L. Hurtado, The Binitarian Pattern of Earliest Christian Devotion and Early Doctrinal Development, [w:] B. D. Spinks, The Place of Christ in Liturgical Prayer. Trinity, Christology and Liturgical Theology, Collegeville 2008, 23-29. Uwagi krytyczne (a przynajmniej próbę ostudzenia nadmiernego entuzjazmu) pod adresem projektu wspomnianych biblistów można znależć w: J. D. G. Dunn, Did the First Christians Worship Jesus? The New Testament Evidence, London 2010, 1-7.

${ }^{20}$ L. Hurtado, Lord Jesus Christ. Devotion to Jesus in Earliest Christianity, Grand Rapids 2005.

${ }^{21} \mathrm{M}$. Hengel, Hymns and Christology, [w:] tenże, Between Jesus and Paul. Studies in the Earliest History of Christianity, London 1983, 78-96.

${ }^{22}$ R. Bauckham, Jesus and the God of Israel. God Crucified and Other Studies on the New Testament's Christology of Divine Identity, Grand Rapids 2008, 127-151.

${ }^{23}$ O. González de Cardedal, Cristología y Liturgia, „Cuadernos Phase” 5 (1988), 11; por. A. Cordovilla, Gloria de Dios y salvación del hombre: una aproximación al cristianismo, Salamanca 1997, 28nn. 
Powróćmy jednak do samej genezy liturgicznej wiary trynitarnej ${ }^{24}$. Istotnie ważny jest tu mandat misyjny z Mt 27, 19-20 (par. Mk 16, 19; $Ł k 24,9$ ). Jest on początkiem - na ile stanowi kulminacje osoby, misji, dzieła i orędzia Jezusa - długiego procesu kształtowania się teologii trynitarnej. Jezus posyła swoich uczniów, aby ci nauczali (czynili uczniów) i chrzcili. Zauważmy, iż sam Jezus wedle znanych nam przekazów nie chrzcił. Nakaz chrztu jest nakazem kultycznym: idzie w nim o konkretny znak, poprzez który człowiek został włączony we wspólnotę z Bogiem. Wspólnota owa - co ważne - nie pozostaje bliżej nieokreślona, lecz jest wyraźnie specyfikowana wspomnieniem imion trzech osób boskich: Ojca, Syna i Ducha Świętego. Chrzest prowadzi zatem do bycia zanurzonym we wspólnotę z Ojcem Jezusa, z samym Jezusem i z Duchem Świętym. Mamy tu do czynienia z wyraźną strukturą trynitarną formuły chrzcielnej, dzięki której sama istota i sens chrztu zostają ustanowione trynitarnie ${ }^{25}$.

Misyjny mandat, jaki Jezus powierzył swoim uczniom, posiada wyraźnie kultyczny charakter. Nakaz chrztu jest nakazem rytualnym - tak przynajmniej był rozumiany od najwcześniejszych czasów ${ }^{26}$. Świadczy o tym chociażby znany fragment Dziejów Apostolskich traktujący o chrzcie dworzanina królowej Etiopskiej Kandaki (Dz 8, 25-40). Chrzest posiada tu już formę sakramentalno-rytualno-symbolicznego zanurzenia w wodzie. Teologia nowotestamentalnych pism ów sakramentalny symbolizm łączyła z wydarzeniem paschy Chrystusa (Rz 6, 1-11; Kol 2, 11-12).

Chrzest jest bezspornie najmocniejszym momentem liturgiczno-kultycznego kształtowania się wiary trynitarnej. Podobnie - aczkolwiek w nieco mniejszym stopniu - jest z instytucją eucharystyczną. Nowotestamentalne teksty odwołują nas w tym względzie do faktycznego wydarzenia, jakim jest ostatnia wieczerza w swoim paradygmatycznym charakterze. Najstarsze świadectwa pawłowe (1 Kor 11, 26) wskazują, iż mandatum Jezusa przekazane podczas ostatniej wieczerzy

${ }^{24}$ F. Young, The Trinity and the New Testament, art. cyt., 288.

${ }^{25}$ F. Courth, Trinität..., dz. cyt., 31.

${ }^{26}$ Miejsce chrztu w uniwersum teologicznym pierwszych chrześcijan przedstawia: G. Theissen, Die Religion der ersten Christen. Eine Theorie des Urchristentums, Gütersloh 2003, 171-194. Na temat socjologicznych wymiarów wczesnochrześcijańskiego rytu chrzcielnego w ich historycznym kontekscie zob. również: G. Theissen, Erleben und Verhalten der ersten Christen. Eine Psychologie des Urchristentums, Gütersloh 2007, 353-365. 
zostało zrozumiane jako wezwanie do kultycznego celebrowania żywej i działającej obecności zmartwychwstałego Pana w swoim Kościele ${ }^{27}$.

Na szczególna uwagę zasługują tu teksty pochodzące z tradycjiJanowej, które widzą Eucharystię jako faktyczną celebrację konstytuującą Kościół (eucharystyczna eklezjogeneza) dzięki jej istotnej i organicznej więzi z wewnętrznym życiem Trójcy. Eucharystia jako celebracja tworząca wspólnotę wierzących w Jezusa jest zakorzenieniem ludzkiego, odnowionego życia w życiu samego Boga. Metafora winnego krzewu (J 15, 1-8) w swojej wybitnie binitarnej formie stanowi podstawę dalszego odsłaniania trynitarnej natury wydarzenia Eucharystii, która dokonuje radykalnego zjednoczenia między sprawującymi ją ludźmi a samym Bogiem. Zjednoczenie to dokonuje się we krwi Jezusa, gdyż to właśnie jego własna tajemnica stanowi pierwotną podstawę liturgii eucharystycznej. Janowa hermeneutyka wydarzenia celebracji liturgicznej jest wybitnie trynitarna. Mowa Eucharystyczna Jezusa w J $6^{28}$ pełna jest aluzji trynitarnych. Jan prezentuje tu eucharystyczny „chleb z nieba” jako fundamentalny dar Ojca $(J n 6,32)$ komunikujący jego życie w Synu (Jn $6,57)$. Eucharystia staje się w ten sposób znakiem, który legitymizuje Jezusa jako przedwiecznego Syna Ojca (J 6, 29-35): doświadczenie eucharystyczne staje się wyjątkowym miejscem zbawczego i życiodajnego doświadczenia synostwa Jezusa. Co więcej, jeśli Jezus jest chlebem Ojca karmiącego wybranych życiem, również i Duch jest życiodajny (J 6, 63; por. J 3, 1-21): Eucharystia jako sakrament ciała Pana uaktywnia się w ożywiającym działaniu Ducha ${ }^{29}$.

W ten sposób pisma tradycji Janowej przyczyniają się do pogłębienia świadomości rzeczywistości już celebrowanej. Okazuje się, że jest ona w swej istocie pogłębieniem i radykalizacją jedności z Chrystusem, który sam stanowi ,jedno z Ojcem”. Eucharystia jest wchodzeniem w logikę boskiego życia trynitarnego. Jan zachęca swoją wspólnotę

${ }^{27}$ J. M. Courth, The Growth of the New Testament, [w:] Oxford Handbook of Biblical Studies, ed. by J. W. Rogerson, J. M. Lieu, Oxford 2008, 531.

${ }^{28}$ Zob. C. Claussen, The Eucharist in the Gospel of John and in the Didache, [w:] Trajectories through the New Testament and the Apostolic Fathers, ed. by A. F. Gregory, Ch. M. Tuckett, Oxford 2005, 135-164.

${ }^{29}$ Por. H. Langkammer, Pneumatologia biblijna, Opole 1998, 133 (Opolska Biblioteka Teologiczna, 27); L. Morris, The Gospel According to John, Grand Rapids 1995, 340-341 (The New International Commentary on the New Testament). 
do uświadomienia sobie i faktycznego przeżycia trynitarnej głębi prawdy celebrowanych rytów.

Pisma Janowe mogą być w tym względzie uznane nie tylko jako podręczniki katechumenatu, ale wyraźne zaproszenie do wtajemniczenia sakramentalnego. Stanowią one swoistego rodzaju teologię liturgiczno-sakramentalną in nuce ${ }^{30}$. Teologia Jana jest teologią chrztu i Eucharystii, dwóch rzeczywistości, które sakramentalnie tworzą Kościół. Jeszcze raz napotykamy zatem potwierdzenie uprzedniości działania liturgicznego względem teologii. Ewangelia i pisma Janowe są bowiem tak skonstruowane, aby stanowić teologiczne pogłębienie świadomości liturgicznie celebrowanego zbawienia.

Taka postać rzeczy uprawnia do stwierdzenia liturgicznego charakteru samej trynitarnej wiary. Oczywiście nie w sensie ograniczenia jego znaczenia jedynie do działalności liturgicznej, której celebracja chrztu i Eucharystii są momentami uprzywilejowanym teologicznie i egzystencjalnie. Stwierdzając liturgiczny charakter trynitarnej wiary Kościoła, mam na myśli jej genezę i najgłębszą naturę, która zawsze zakłada liturgiczne i perychoretyczne współbycie z Trójjedynym Bogiem. Organiczny i genetyczny związek między treścią wiary i celebracją jest takiej natury, że odsłania przed człowiekiem prawdę jego nowego bycia, które całe jest uczestnictwem, ofiarowanym współbyciem (Mit-sein $\left.{ }^{31}\right)$ z Trójjedynym Bogiem. Liturgia sama w sobie jest teologią fundamentalną ${ }^{32} \mathrm{i}$ już zawsze jednocześnie ontologią fundamentalną. W niej bowiem pierwotnie odsłania się boskie trynitarne bycie-w-sobie jako trynitarne i relacyjne Mit-sein agapicznie dzielone w absolutnej i nieumniejszonej niczym boskiej wolności z człowiekiem.

Liturgicznie osadzony początek teologii trynitarnej słusznie bywa określany mianem performatywnej teologii trynitarnej (performati-

${ }^{30}$ R. E. Brown, An Introduction to the Gospel of John, dz. cyt., 229-233.

${ }^{31}$ Pojęcie Mit-Sein lub Miteinandersein pochodzi z metafizyki M. Heideggera, w której stanowi jedno z podstawowych określeń ludzkiego bycia; por. L. P. Hemming, One God, One's Self, One World. Being with Others, Oxford 2010.

${ }^{32}$ A. Grillo, Teologia fondamentale e liturgia. Il rapporto tra immediatezza e mediazione nella riflessione teologica, Padova 1995 (Caro Salutis Cardo. Studi, 10); tenże, Introduzione alla teologia liturgica. Approccio teorico alla liturgia e ai sacramenti cristiani, Padova 1999 (Caro Salutis Cardo. Sussidi, 3). 
ve Trinitätstheologie) $)^{33}$. Performatywność, o którą idzie, związana jest z rytualnym kształtem pierwotnej wiary trynitarnej. Wiara ta nie jest jedynie pustym wyznaniem. Posiada ona bowiem konkretne efekty, jest operatywna, działająca, ożywiająca i skuteczna. Co więcej, pierwotna teologia trynitarna jest chrześcijańską praxis sakramentalno-liturgiczną. Celebracje chrztu i Eucharystii są dla pierwszych chrześcijan podstawowymi formami wyrazu ich wiary. Liturgia staje się w ten sposób działaniem czysto teologicznym, fundamentalną postacią samej teologii. Teologia trynitarna u swoich początków posiada zatem wybitnie praktyczną strukturę i naturę.

To wszystko uprawnia do wyciągnięcia wniosków. Pierwszym z nich jest stwierdzenie fundamentalnej i mocnej nieodłączności wiary trynitarnej i liturgii u samych źródeł. Drugim wnioskiem - organicznie związanym z pierwszym - jest nieodłączność sakramentu i liturgii, liturgii i sakramentu ${ }^{34}$. Druga ze wspomnianych „niedłączności” stanowi fundament pierwszej: związek liturgii i teologii trynitarnej zakorzeniony jest w paschalnej dynamice jedności działania liturgiczno-sakramentalnego. Okazuje się, iż od samych swoich początków teologia trynitarna łączy się ściśle z historycznym faktem zbawienia, również w jego sakramentalnej konstelacji. Narodziny teologii trynitarnej wewnątrz liturgiczno-sakramentalnej celebracji świadczą dobitnie o jej egzystencjalnym charakterze. Jednocześnie jedynie teologia trynitarna zdolna jest oddać pojęciowo egzystencjalne bogactwo doświadczenia chrześcijańskiego, którego wyraz stanowi liturgia. Teologia trynitarna posiada wyraźne cechy liturgicznej teorii hermenutycznej, wszak stanowi ona jedyny adekwatny opis owego pradoświadczenia chrześcijańskiego, z którego narodziło się działanie liturgiczne. W tym sensie to właśnie liturgia stanowiła z historycznego punktu widzenia konieczny pomost między owym pradoświadczeniem a explicite wyrażoną prawdą wiary. Liturgiczny początek wiary i teologii trynitarnej explicite oznacza, iż to właśnie liturgia stanowiła adekwatną kondensację pradoświadczenia

${ }^{33}$ T. Söding, Ein Gott - Ein Herr - Ein Geist. Die neutestamentliche Trinitätstheologie und ihre liturgische Bedeutung, [w:] Liturgie und Trinität, dz. cyt., 28-39.

${ }^{34}$ A. Grillo, Teologia sacramentaria, teologia liturgica e teologia fondamentale: verso una convergenza, [w:] Corso di teologia sacramentaria, t. 1: Metodi e prospettive, edd. A. Grillo, M. Perroni, P.-R. Tragan, Brescia 2000, 108-136. 
chrześcijańskiego, która wyartykułowała prawdę owego doświadczenia w jasnych kategoriach pojęciowych. Z tego powodu teologia trynitarna stanowi nie tylko adekwatny opis samego pradoświadczenia, ale i powstałej z niego liturgii. Teologia liturgii musi być zatem radykalnie i nieodwołalnie trynitarna. Teologia zaś trynitarna musi być teorią liturgiczną, to znaczy musi budować się i odwoływać do doświadczenia liturgicznego, które stanowi odzwierciedlające trwanie pradoświadczenia chrześcijańskiego. Takie umiejscowienie teologii trynitarnej wewnątrz uniwersum liturgicznego jest szansą ożywienia nie tylko samej teologii trynitarnej poprzez nadanie jej pojęciom egzystencjalno-praktycznego wymiaru, lecz nade wszystko samej praktyki liturgicznej poprzez jej trynitarne wyjaśnienie. Takie zaś wyjaśnienie nadaje liturgii całkiem nowy sens: została ona bowiem pojęta jako prawdziwie zbawcze spotkanie i dialog z żyjącym i prawdziwym Ojcem Jezusa w Duchu Świętym.

Trynitarność działania liturgiczno-sakramentalnego

w teologii patrystycznej

U podstaw trynitarnego rozumienia wydarzenia chrztu w epoce patrystycznej odnajdujemy nie tylko zauważone powyżej świadectwo ewangeliczne, ale i wybitnie trynitarną interpretację chrztu Jezusa w Jordanie. Aczkolwiek pierwsi chrześcijanie zdawali sobie sprawę z zasadniczej różnicy, jaka dzieli chrzest Janowy od chrztu sakramentalnego, ich rozumienie tego drugiego odwołuje się i buduje na bazie trynitarnie interpretowanego chrztu w Jordanie ${ }^{35}$.

$\mathrm{Na}$ faktyczność kategorialnego związku między wiarą trynitarną i liturgią chrzcielną zwracają uwagę zarówno teksty magisterium ${ }^{36}$, jak i wczesne dogmatyczne syntezy wiary będące w dużej mierze uważną

${ }^{35} \mathrm{~K} . \mathrm{McD}$ onnell, The Baptism of Jesus in the Jordan. The Trinitarian and Cosmic Order of Salvation, Collegeville 1996, 188-200, 236-237; M. E. Johnson, The Rites of Christian Initiation. Their Evolution and Interpretation, Collegeville 2007, 63.

${ }^{36}$ Wymienić tu należy nade wszystko 9 (8) kanon Synodu w Arles (314), który zwraca uwagę na konieczność użycia prawowiernej formuły chrzcielnej do ważności chrztu. Formuła ta to oczywiście wezwanie Trójcy - zob. Dokumenty synodów od 50 do 381 roku, układ i oprac. A. Baron, H. Pietras, Kraków 2006, 72-73 (Źródła Myśli Teologicznej, 37). 
lekturą świadectwa Pisma, zaproponowane przez Ireneusza z Lyonu, Hipolita Rzymskiego ${ }^{37}$ i Tertuliana ${ }^{38}$.

Ireneusz z Lyonu to jeden z pierwszych świadków rodzącej się refleksji teologicznej w chrześcijaństwie. To właśnie on proponuje zwięzłą formułę wiary, którą określa mianem reguły wiary ${ }^{39}$. Co istotne z punktu widzenia niniejszej prezentacji, owa zwięzła i wczesna formuła wiary jest trynitarna i jednocześnie chrzcielna. W wykładzie zasad wiary Epideixis Ireneusz stwierdza: „Dlatego chrzest naszego odrodzenia (palingenesia) dokonuje się przez te trzy artykuły, obdarzając nas zrodzeniem (anagennesis) ku Bogu Ojcu przez jego Syna w Duchu Świętym" 40

Trynitarna reguła wiary, zaczątek późniejszego symbolu (wyznania wiary), jest tu wyraźnie widoczna. Pomiędzy celebracją chrztu i trynitarną wiarą zachodzi istotna relacja: chrzest jako wejście w wiarę jest jednocześnie wejściem we wspólnotę z Trójjedynym Bogiem. To sam chrzest jest najbardziej podstawową, symboliczno-rytualną regułą wiary. $Z$ reguły tej powstało pełne chrzcielne wyznanie wiary ${ }^{41}$.

Podobne ujęcia spotykamy w teologii wieku IV, kluczowym dla rozwoju i wypracowania lingwistycznych oraz semantycznych reguł trynitarnej świadomości. Jest to zasada ważna zarówno dla chrześcijańskiego wschodu, jak i zachodu. Za przykład mogą tu służyć chociażby

${ }^{37}$ Hipolit Rzymski, Traditio Apostolica, 21.

${ }^{38}$ Tertulian, De anima, 1; De baptismo, 3; De spectaculis, 4. Na temat wczesnej postaci rytualnej chrztu i jej teologicznej hermeneutyki zob. B.D. Spinks, Early and Medieval Rituals and Theologies of Baptism. From the New Testament to the Council of Trent, Aldeshot 2006.

${ }^{39}$ Ireneusz z Lyonu, Wykład nauki apostolskiej, 6: „A to jest porządek naszej wiary i podstawa (naszej) budowy i oparcie dla obyczaju. Bóg Ojciec niestworzony, niepojęty, niewidzialny, jeden Bóg, stwórca wszystkiego: to pierwszy artykuł naszej wiary. Drugi artykuł zaś to: Słowo Boże, Syn Boży, Jezus Chrystus, nasz Pan, który objawił się prorokom według właściwości ich prorokowania i według stanu zrządzenia Ojca, przez którego wszystko się stało, który w ostatnim czasie, aby sprowadzić wszystko w jedno, stał się człowiekiem wśród ludzi, widzialnym i dotykalnym, dla zniszczenia śmierci i ukazania życia i zaprowadzenia wspólnoty człowieka z Bogiem! A to trzeci artykuł: Duch Święty przez którego prorocy przepowiadali i ojcowie nauczali o sprawach Bożych, a sprawiedliwi kierowali się na drogę sprawied1iwości i który w ostatnim czasie został wylany w nowy sposób na ludzkość odnawiając człowieka po całej ziemi dla Boga".

${ }^{40}$ Ireneusz z Lyonu, Wykład nauki apostolskiej, 7; zob. tenże, Adversus haereses, I, 10, 1-2.

${ }^{41}$ Por. M. Fiedrowicz, Theologie der Kirchenväter. Grundlagen frühchristlischer Glaubensreflexion, Freiburg-Basel-Wien 2007, 188-208. 
teksty De Spiritu Sancto Bazylego Wielkiego i Ambrożego z Mediolanu. W obydwu przypadkach mamy do czynienia z dziełami fundamentalnymi dla dopracowującej się teologii trynitarnej, które wiążą teologię trynitarną z wydarzeniem chrztu.

Zdaniem obu ojców formuła chrzcielna stanowi podstawę właściwego wyznawania wiary. Stanowi ona dlatego podstawowy argument chociażby za bóstwem Ducha Świętego. Bazyli ${ }^{42}$ podkreśla, iż to właśnie chrzest uczy prawdziwej wiary trynitarnej ${ }^{43}$. Sama formuła chrzcielna w swoistej dla siebie koordynacji imion stanowi dla Bazylego podstawę, aby wnioskować, iż relacja Ducha Świętego do Syna jest podobna do tej, jaką Syna ma w stosunku do Ojca ${ }^{44}$. Ambroży ${ }^{45}$ zwraca uwagę, iż chrzest może być uznany za ważny, tylko gdy zostanie dokonany w imię trzech. Opuszczenie jednej z osób powoduje nieważność sakramentu $^{46}$. Chrzest zostanie dokonany i dopełniony tylko i wyłącznie, gdy towarzyszy mu otwarte wyznanie wiary trynitarnej w Ojca, Syna i Ducha Świętego. Stąd też Ambroży podkreśla stanowczo różnicę, jaka istnieje pomiędzy chrztem Janowym a chrztem Chrystusa. Tylko ten ostatni jest rzeczywistością oferująca zbawienie, a dokonuje się to poprzez włączenie chrzczonej osoby w komunię trynitarną poprzez wyznanie wiary w Trójcę ${ }^{47}$. Działanie Ducha Świętego w sakramencie chrztu i wyraźne przywołanie jego imienia w formule sakramentalnej stanowi dla Ambrożego wyraźny znak i dowód boskiego charakteru trzeciej osoby ${ }^{48}$.

${ }^{42}$ Na temat jego teologii trynitarnej zob. V.H. Drecoll, Die Entwicklung der Trinitätslehre des Basilius von Cäsarea. Sein Weg vom Homöusianer zum Neonizäner, Göttingen 1996 (Forschungen zur Kirchen-und Dogmengeschichte, 66); B. Sesboüé, Saint Basile et la Trinité: Un acte théologique du IVe siècle, Paris 1998; S. M. Hildebrand, The Trinitarian Theology of Basil of Caesarea. A Synthesis of Greek Thought and Biblical Truth, Washington D.C. 2007.

${ }^{43}$ Bazyli Wielki, De Spiritu Sancto, 10, 26 i 12.

${ }^{44}$ Tamże, 17, 43.

${ }^{45} \mathrm{Na}$ temat teologii trynitarnej Ambrożego zob. D. H. Williams, Ambrose of Milan and the End of Nicene-Arian Conflict, Oxford 1995 (Oxford Early Christian Studies); Ch. Markschies, Ambrosius von Mailand und die Trinitätstheologie, Tübingen 1995 (Beiträge zur Historischen Theologie, 90).

${ }^{46}$ Ambroży, De Spiritu Sancto, 3.

${ }^{47}$ Ambroży, De Spiritu Sancto, 3, 41-44.

${ }^{48}$ Tamże, 4, 55 i 5. 
Jasno pokazuje to związek wiary trynitarnej z sakramentem chrztu, który stanowi jej bliższe źródło i podstawową weryfikację $e^{49}$.

Wybitnie trynitarną teologię sakramentalnego działania liturgicznego napotykamy w De Mysteriis Ambrożego. Jej podstawą jest trynitarne działanie stwórcze wspólne Ojcu, Synowi i Duchowi Świętemu. Pomiędzy liturgicznym misterium a działaniem stwórczym zachodzi głęboka jedność. Liturgia wpisuje się w logikę działania stwórczego, które stoi u jej podstaw. Ambroży, posługując się nośnymi stwierdzeniami Ps 22, 6: „Verbo Domini coeli firmati sunt, et Spiritu oris ejus omnis virtus eorum", stwierdza, iż stworzenie jest miejscem działania Słowa Bożego i Ducha Pańskiego. Interpretacja Ambrożego opiera się na rozległej trawestacji starotestamentalnej teologii stworzenia poprzez wydarzenie Chrystusa i przyjście Ducha Świętego. To właśnie w ich świetle stworzenie może zostać uznane za prefigurację boskiego działania w sakramentalnych misteriach. Kategoria działania (operatio) stanowi tu klucz i fundament trawestacji i transpozycji ideowej, która pozwala nadać słowom starotestamentalnego psalmu wyraźnie trynitarną i sakramentalną konotację. Działanie sakramentalne, misteryjne zostało pierwszorzędnie wpisane i ujęte wewnątrz stwórczego działania Bożego jako jego szczególny modus: tajemnice są ujęte figuratywnie już w samym origo świata ${ }^{50}$.

Trynitarność sakramentalnego działania liturgicznego odsłania się w szczególny sposób, kiedy Ambroży przechodzi do omówienia formuły chrzcielnej.Jego istotna część poświęcona jest wykazaniu jedności trzech na podstawie jedności samej formuły i chrzcielnego Credo, które zdaniem Ambrożego wyklucza jakiekolwiek subordynacjonistyczne interpretacje ${ }^{51}$.

${ }^{49}$ Bazyli Wielki, De Spiritu Sancto, 27, 67

${ }^{50}$ Ambroży, De Mysteriis, 9: „Considera autem quam vetus mysterium sit, in ipsius mundi praefiguratum origine. In principio ipso, quando fecit Deus coelum et terram, Spiritus, inquit, superferebatur super aquas (Gen. I, 2). Qui superferebatur super aquas, non operabatur super aquas? Sed quid dicam operabatur? quod ad praesentiam spectat, superferebatur. Non operabatur, qui superferebatur? Cognosce quia operabatur in illa mundi fabrica, quando tibi dicit Propheta: Verbo Domini coeli firmati sunt, et Spiritu oris ejus omnis virtus eorum (Psal. XXXII, 6). Utrumque prophetico subnixum est testimonio, et quia superferebatur et quia operabatur. Quia superferebatur, Moyses dicit: quia operabatur, David testificatur”.

${ }^{51}$ Ambroży, De Mysteriis, 28: „Descendisti igitur; recordare quid responderis, quod credas in Patrem, credas in Filium, credas in Spiritum sanctum. Non habes illic: Credo in majorem et minorem et ultimum: sed eadem vocis tuae cautione constringeris, ut si- 
Jednocześnie wspólne działanie osób boskich zostało przez Ambrożego wyraźnie oznakowane: to Bóg Ojciec opieczętowuje swoich wybranych, umacnia ich Chrystus Pan, a Duch Święty wyciska w ich sercach swoje znamię. Chrzest jako liturgiczno-sakramentalne actio to wspólne i nierozdzielne działanie Trójcy o wyraźnie wyspecyfikowanych trzech momentach przypisanych poszczególnym osobom trynitarnym ${ }^{52}$.

Podobnie jak w De Spiritu Sancto, także w De Mysteriis Ambroży przykłada wielkie znaczenie do działania Ducha Świętego, bez którego pomocy nie jest możliwe, aby „woda oczyszczała” (aquam non mundare sine Spiritu $)^{53}$. Tajemnica odrodzenia dokonuje się jego boską mocą. Działanie Ducha Świętego ujęte jest jednak integralnie w perspektywie działania Chrystusa, na co wyraźnie wskazuje fragment alegoryczno-sakramentalnego odczytania wydarzenia uzdrowienia chromego opisane w J 5, $4^{54}$.

Podobnie i analogicznie jak z chrztem rzecz ma się z Eucharystią. Trynitarny charakter liturgii eucharystycznej widać bardzo wyraźnie w wielu tekstach starożytnych ${ }^{55}$. Chrześcijanie od samego początku

militer credas in Filium, sicut in Patrem credis: similiter in Spiritum sanctum credas, sicut credis in Filium; hoc solo excepto, quod in crucem solius Domini Jesu fateris tibi esse credendum".

${ }^{52}$ Ambroży, De Mysteriis, 42: „Unde repete quia accepisti signaculum spiritale, spiritum sapientiae et intellectus, spiritum consilii atque virtutis, spiritum cognitionis atque pietatis, spiritum sancti timoris (Esai. XI, 2): et serva quod accepisti. Signavit te Deus Pater, confirmavit te Christus Dominus; et dedit pignus Spiritus in cordibus tuis, sicut Apostolica lectione didicisti (II Cor. V, 2)".

${ }^{53}$ Ambroży, De Mysteriis, 42: „Aquam non mundare sine Spiritu, Joannis testimonio et ipsis quibus idem sacramentum administratur, verbis declaratur. Quod etiam asseritur significatum per Evangelicam piscinam, et paralyticum a Domino ibi sanatum: quo loco Spiritus sanctus in ejusdem Christi baptismo verte descendisse ostenditur, et quid in hoc mysterio intelligendum?".

${ }^{54}$ Ambroży, De Mysteriis, 22: „Ideo tibi dictum est: Quia angelus Domini descendebat secundum tempus in natatoriam, et movebatur aqua; et qui prior descendisset in natatoriam post commotionem aquae, sanus fiebat a languore quocumque tenebatur (Joan. V, 4). Haec piscina in Hierosolymis erat, in qua unus annuus sanabatur: sed nemo ante sanabatur, quam descendisset angelus. Ut esset indicium quia descenderat angelus, movebatur aqua propter incredulos. Illis signum, tibi fides: illis angelus descendebat, tibi Spiritus sanctus: illis creatura movebatur, tibi Christus operatur ipse Dominus creaturae".

${ }^{55}$ Por. R. J. Daly, Trinitarian Theology in Early Christian Anaphoras, [w:] God in Early Christian Thought: Essays in Memory of Lloyd G. Patterson, ed. by A. B. McGowan, B. E. Daley, 
wiedzieli, iż Eucharystia jest wydarzeniem nie tylko chrystologicznym, ale i paradygmatycznie pneumatologicznym ${ }^{56} \mathrm{i}$ jako taka posiada związek z Ojcem, który posyła Syna i Ducha Świętego dla zbawienia świata. Doksologiczno-trynitarne ujęcie Eucharystiii ${ }^{57}$ widać już wyraźnie u Justyna ${ }^{58}$ i u Hipolita ${ }^{59}$. Na szczególną uwagę zasługuje tutaj rozumienie Eucharystii, jakie spotykamy w teologii syryjskiej. Jej anafory eucharystyczne - zresztą jak większość anafor wschodnich - jest ściśle trynitarna zarówno w swojej strukturze jak i treści ${ }^{60}$.

Potwierdzeniem istotnego związku zachodzącego między teologią trynitarną i liturgią eucharystyczną jest kwestia epiklezy ${ }^{61}$. Idzie tu szczególnie o średniowieczny spór o miejsce i status epiklezy. Jego przedmiotem była czynna obecność Ducha Świętego i statut jego aktualizującego działania w liturgii. Spór ten wyraźnie pokazuje, iż Eucharystia dokonuje się zarówno jako czyn Chrystusa, jak i jednocześnie jako czyn Ducha Świętego, którzy pozostają w stosunku do siebie w nierozdzielnej jedności życia i działania ${ }^{62}$.

Osobną kwestiązasługującą na specjalne potraktowanie jest zagadnienie doksologii liturgicznej w jej związku z wiarą trynitarną ${ }^{63}$. Powszechnym zwyczajem w Kościele było adresowanie modlitw liturgicznych do Ojca przez (dia) Syna, przez lub w (en) Duchu Świętym ${ }^{64}$ bądź też wychwalanie Ojca przez Syna w Duchu Świętym. Ta pierwotna formuła została

T. J. Gaden, Leiden 2009, 239-270 (Vigilae Christiane. Supplements, 94).

${ }^{56}$ Zob. Le Saint-Esprit dans la liturgie. Conférences Saint-Serge, XVIe semanine d'études liturgiques, Paris, 1-4 juillet 1969, Roma 1977, 7-11 (Bibliotheca Ephemerides Liturgicae. Subsidia, 8).

${ }^{57}$ Mateo-Seco, Dios, 151-152.

${ }^{58}$ Justyn, Apologia Pierwsza, 65.

${ }^{59}$ Hipolit, Traditio Apostolica, 4.

${ }^{60}$ B. Vargese, West Syriac Liturgical Theology, Aldershot 2004, 53nn (Liturgy, Worship and Society).

${ }^{61}$ P.-M. Gy, Épiclèse, [w:] J.-Y. Lacoste, Dictionnaire critique de théologie, Paris 1998, 393-394.

${ }^{62}$ Cyryl Jerozolimski pisze o przedkonsekracyjnym wezwaniu całej Trójcy - zob. Myst., III, 3, 7.

${ }^{63} \mathrm{~A}$. Gerhards, La doxologie, un chapitre définitifdel'histoire de dogme?, Trinité et liturgie. Conférences Saint-Serge XXXe Semaine d'Études Liturgiques, Roma 1984, 103-118.

${ }^{64}$ Por. Hipolit Rzymski, Traditio Apostolica, 3, 6; Klemens Aleksandryjski, Quis dives salvetur, 42, 20; Orygenes, Or., 33, 1.6. 
w ferworze sporów ariańskich w IV w. przekształcona przez Bazylego Wielkiego ${ }^{65} \mathrm{~W}$ taki sposób, aby uniknać subordynacjańskiej wieloznaczności związanej z wyrażeniem dia, które zostało zastąpione z biegiem czasu przez nadające się lepiej do wyrażenia jedności i równości kai ${ }^{66}$. Doksologia spełniała również zasadniczą funkcję w liturgii syryjskiej, w której przybrała bardziej rozbudowaną postać. Za przykład niech posłuży anafora Sewera z Antiochii: „Chwała niech będzie Ojcu, który posłał swojego Syna do śmiertelników; adoracja Synowi, który ich ożywił przez swoją ofiarę; cześć i uznanie Duchowi Świętemu, który ich wskrzesi z prochu. O Trójco adorowana przez wszytkich, Tobie chwała" ${ }^{67}$. Zwrócić należy uwagę na wybitnie historiozbawczą orientację przytoczonej doksologii. Uwielbienie, jakie Kosciół oddaje liturgicznie Bogu, zakotwiczone jest w trynitarnym działaniu zbawczym w świecie. Uwielbienie to zatem odnosi się nie tylko do Boga w jego transcendentnym bóstwie, ale i do Boga zaangażowanego w dzieje świata.

\section{Trynitarność liturgii według Vaticanum II}

Trynitarne ujęcie rzeczywistości liturgicznej to całkiem nowy trop w dokumentach magisterium. Na wyraźnie trynitarny charakter i istotę kultu liturgicznego zwrócił uwagę Sobór Watykański II. Przyjdzie nam teraz zmierzyć się z jego ujęciem teologii liturgii poprzez teologię trynitarną.

Nie ulega wątpliwości, iż sobór myśli o liturgii jako o dziele całej Trójcy. Na uwagę zasługuje wybitnie teologiczny charakter tekstów konst. Sacrosanctum Concilium, szczególnie jej wprowadzającego rozdziału, w którym zaprezentowano wizję liturgicznego misterium od strony jego istoty. Rozważmy następujący fragment konstytucji: "Ideoque, sicut Christus missus est a Patre, ita et ipse Apostolos, repletos Spiritu Sancto, misit, non solum ut, praedicantes Evangelium omni creaturae, annuntiarent Filium Dei morte sua et resurrectione

${ }^{65}$ Bazyli Wielki, De Spiritu Sancto, 29, 73.

${ }^{66}$ H. J. Feulner, Doxologie. IV. Liturgisch, [w:] Lexikon für Theologie und Kirche, t. 3, Freiburg im Breisgau 1959, 357; T. Federici, Doxología, [w:] El Dios Cristiano. Diccionario Teológico, dirs. X. Pikaza, N. Silanes, Salamanca 1992, 361.

${ }^{67}$ Sewer z Antiochi, Hymn 15, 17 (Partologia Orientalis, 6.1). 
nos a potestate satanae et a morte liberasse et in regnum Patris transtulisse, sed etiam ut, quod annuntiabant, opus salutis per Sacrificium et Sacramenta, circa quae tota vita liturgica vertit, exercerent. Sic per Baptismum homines paschali Christi mysterio inseruntur: commortui, consepulti, conresuscitati; piritum accipiunt adoptionis filiorum, «in quo clamamus: Abba, Pater» (Rom 8, 15), et ita fiunt veri adoratores, quos Pater quaerit. Similiter quotiescumque dominicam cenam manducant, mortem Domini annuntiant donec veniat. Idcirco, ipsa die Pentecostes, qua Ecclesia mundo apparuit, «qui receperunt sermonem» Petri «baptizati sunt». Et erant «perseverantes in doctrina Apostolorum et communicatione fractionis panis et orationibus... collaudantes Deum et habentes gratiam ad omnem plebem» (Act 2, 41-42, 47). Numquam exinde omisit Ecclesia quin in unum conveniret ad paschale mysterium celebrandum: legendo ea «in omnibus Scripturis quae de ipso erant» (Lc 24, 27), Eucharistiam celebrando in qua «mortis eius victoria et triumphus repraesentantur», et simul gratias agendo «Deo super inenarrabili dono» $(2$ Cor 9,15$)$ in Christo Iesu, «in laudem gloriae eius» (Eph 1,12 ), per virtutem Spiritus Sancti” (konst. Sacrosanctum Concilium, 6).

Jak nietrudno zauważyć, podstawą teologii liturgii jest teologia misji trynitarnych, która tradycyjnie opisywała zaangażowanie boskich osób w dzieje zbawienia. Zgodnie z tradycyjnym ujęciem missio oznacza posłanie jednej z boskich osób przez inną. Misja jest ekonomicznym przedłużeniem wewnątrztrynitarnych, immanentnych pochodzeń: zrodzenia i tchnienia. Stąd Ojciec przez nikogo nie jest posłany, ale sam - jako principium totius divinitatis - jest źródłem posłania Syna i Ducha Świętego. Ojciec jako początek (arche, principium) boskości, boskiego bytu jest równocześnie początkiem wszelkiego działania w Trójcy i Trójcy w świecie. Posyłając Syna i Ducha, w których odbija się cała logika jego ojcowskiej miłości, sam czyni siebie obecnym w historii świętej.

Logika odpowiedniości pochodzeń i misji wpisuje się w istotne dla chrześcijaństwa rozróżnienie immanencji i ekonomii, czyli porządku boskiego życia wewnętrznego (Bóg w sobie) i jego bycia dla nas związanego z byciem w świecie. To fundamentalne rozróżnienie wypracowane w czasach Ireneusza i Tertuliana ${ }^{68}$ nie jest natury dialektycznej,

${ }^{68}$ Zob. G. Richter, Oikonomia. Der Gebrauch Des Wortes Oikonomia im Neuen Testament, bei den Kirchenvatern und in der theologischen Literatur bis ins 20. Jahrhundert, Berlin 2005 
rozróżnienie nie jest tu rozdzieleniem. W misjach bowiem odsłaniają się boskie wewnętrzne pochodzenia. Misja Syna i Ducha Świętego nie tylko objawia porządek pochodzeń w Bogu, ale nade wszystko sprawia, że one w sposób właściwy ekonomii dokonują się w świecie. Synostwo Syna zostało przyniesione, zaczyna istnieć w świecie od momentu wcielenia, podobnie jak i boska geneza Ducha staje się obecna historycznie w przyjściu trzeciej boskiej osoby do świata. Misje sprawiają, że boskie trynitarne życie uobecnia się pośrodku świata w całej swojej dynamicznej naturze. Rzeczy boskie i ludzkie przenikają się, współistnieją na zasadzie miłującego i wolnego upodobania Ojca odsłoniętego i zrealizowanego w Synu i Duchu Świętym. Grzegorz z Nyssy pisał o owym współprzenikaniu (akoluthia), widząc w niej istotny wymiar teologii historii69.

Jednocześnie konst. Sacrosanctum Concilium, 6 wiąże posłania trynitarne z misją nadaną przez Jezusa zmartwychwstałego apostołom. Trwanie trynitarnych misji Syna i Ducha Świętego związane jest z posłaniem apostołów: samo to posłanie stanowi analogicznie przedłużenie posłania Syna i Ducha Świętego przez Ojca. Właśnie wewnątrz misji apostołów znajduje się liturgia jako istotna część ich zadania. Liturgiczne dokonywanie dzieła zbawienia przez ofiarę i sakramenty posiada znaczenie wpisane w szerszy sens ekonomicznego zaangażowania się Trójjedynego Boga. Tak jak Ojciec posyła Syna, tak Syn wybiera i posyła apostołów, aby głosili i sprawowali tajemnicę zbawienia. Apostolskie i kościelne działanie liturgiczno-sakramentalne czerpie swe żywo źródło z Ojca, który posyła Syna i Ducha Świętego. Kościelny wymiar liturgii nie znajduje się na marginesie jej trynitarnej struktury $\mathrm{i}$ istoty, lecz zgodnie z zamysłem bożym jest dla niej konstytutywny. Nie stanowi zatem wyparcia trynitarnego rytmu liturgii, lecz jego konkretną, trwającą w czasie i miejscu formę.

Należy zwrócić uwagę, iż konst. Sacrosanctum Concilium, 6 wpisuje się w zasadniczą intuicję chrześcijańskiej tradycji trynitarnej, odwołując się do wszystkich jej istotnych wymiarów. Świadczy o tym wyraźne odwołanie się do porządku wewnątrztrynitarnych pochodzeń (Ojciec posyła

(Arbeiten zur Kirchengeschichte).

${ }^{69} \mathrm{G}$. Maspero, La teologia della storia di Gregorio di Nissa, „Excerpta e Dissertationibus in Sacra Theologia" 45 (2003), 383-451; J. A. Gil-Tamayo, Akoluthia, [w:] Diccionario de San Gregorio de Nisa, directores de la edición L. F. Mateo-Seco, G. Maspero, Burgos 2006, 54-63. 
Syna i Ducha), które stanowią fundament wydarzenia liturgicznego, również w jego apostolsko-kościelnej konstytucji. To oznacza, iż relacjami zachodzącymi między liturgią a Trójcą rządzić muszą te same prawidła, które regulują odniesienie immanencji do ekonomii. Liturgia jest tutaj casus specialis. Okazuje się bowiem, że jej rozumienie jest ściśle uzależnione od wcześniejszego uchwycenia wewnętrznej gramatyki trynitarnej wiary Kościoła. Teologia liturgii funduje się na teologii trynitarnej, jest jej modusem istnienia. Wydaje się, że od strony teoretycznej konst. Sacrosanctum Concilium, 6 jest jednym z najbardziej trynitarnych tekstów magisterium poświęconych liturgii. Jest to ważne, o ile stanowi wyraźny i zdecydowany znak teologicznego rozumienia liturgii ${ }^{70}$.

Pojęcie usynowienia odgrywa w trynitarnym pojmowaniu teologicznego charakteru wypowiedzi konst. Sacrosanctum Concilium, 6 zasadniczą wagę. Jest to zarazem jedno z kluczowych pojęć teologii trynitarnej: immanentny akt rodzenia dotyczy Syna, które to imię jest imieniem własnym drugiej osoby Trójcy. Wspomniane u samego początku punktu misje Syna i Ducha mają za swój przedmiot usynowienie, czyli włączenie w synostwo Syna ludzi. Jak widać owa „synowska adopcja”, dzieło Syna i Ducha w świecie, nie jest obca istocie liturgii. Usynowienie to dokonuje się na drodze włączenia człowieka w synostwo jedynego, przedwiecznego Syna poprzez włączenie go w misterium paschalne, które znów dokonuje się fundamentalnie w liturgiczno-sakramentalnym wydarzeniu chrztu. Trynitarny fundament liturgii związany z teologią misji został ujęty w ten sposób soteriologicznie.

Trynitarność liturgii związana jest organicznie z chrystologią. W ten sposób tekst zachowuje porządek trynitarnego objawienia, które dokonuje się pierwszorzędnie w osobie wcielonego Syna ${ }^{71}$. Jeśli jeden z Trójcy jest liturgiem, liturgia jest dziełem całej Trójcy. Trynitarność liturgii czerpie swe źródło konkretnie w misji Syna.

${ }^{70}$ Wynika z tego bezpośredni wniosek natury metodologicznej: dogmatyka nie powinna abstrahować od wydarzenia liturgicznego, a liturgia powinna świadomie żyć głębią wyznawanej prawdy wiary, stanowić jej celebracyjną mo dalność.

${ }^{71}$ Zob. R. J. Woźniak, Liturgia i revelación. Naturaleza litúrgico-sacramental de la revelación cristiana, [w: J. L. Gutiérrez, F. M. Arocena, P. Blanco, La liturgia en la vida de la Iglesia, Pamplona 2007, 99-111 (Simposios Internacionales de Teología, 27). 
"Ad tantum vero opus perficiendum, Christus Ecclesiae suae semper adest, praesertim in actionibus liturgicis. Praesens adest in Missae Sacrificio cum in ministri persona, «idem nunc offerens sacerdotum ministerio, qui seipsum tunc in cruce obtulit», tum maxime sub speciebus eucharisticis. Praesens adest virtute sua in Sacramentis, ita ut cum aliquis baptizat, Christus ipse baptizet. Praesens adest in verbo suo, siquidem ipse loquitur dum sacrae Scripturae in Ecclesia leguntur. Praesens adest denique dum supplicat et psallit Ecclesia, ipse qui promisit: «Ubi sunt duo vel tres congregati in nomine meo, ibi sum in medio eorum» (Mt 18, 20). Merito igitur Liturgia habetur veluti Iesu Christi sacerdotalis muneris exercitatio, in qua per signa sensibilia significatur et modo singulis proprio efficitur sanctificatio hominis, et a mystico Iesu Christi Corpore, Capite nempe eiusque membris, integer cultus publicus exercetur" (konst. Sacrosanctum Concilium, 7).

Jak słusznie zauważono, 7 punkt konstytucji jest nieco chrystomoniczny. Osoba Ducha Świętego nie pojawia się w nim jako zasadnicza $\mathrm{i}$ istotna ${ }^{72}$. Centrum zainteresowania stanowi tu obecność (presentia), żywa i działająca, Chrystusa Pana. Formuła Christus adest posiada w tym kontekście metafizyczny wydźwięk. Obecność Chrystusa w Kościele i jego liturgicznych czynnościach jest formą „bycia przy” - ożywczego i sprawczego towarzyszenia. Obecność w chrystologii liturgii staje się podstawą teologii działania: działanie zakorzenione jest w obecności.

Ciekawym uszczegółowieniem i uzupełnieniem doktryny liturgicznej Vaticanum II jest Katechizm Kościoła katolickiego. Katechizm opisuje liturgię jako trynitarny ruch, który od Ojca bierze początek ${ }^{73}$, przechodzi przez

${ }^{72}$ „Die Wesenbeschreibung der Liturgie in SC 7, Abs. 3 bedarf freilich einer Ergänzung. In ihr wird der Heilige Gesit nich erwähnt. Der Bund zwischen Gott und Menschen wird aer aktualisiert nicht nur durch Christus, sondern auch im Heiligen Geist. Liturgie wird vollzogen im Heiligen Geist, der ebenso wie in Jesu priesterlischen Wirken auch in dem der Kirche gegenwärtige ist. Heilsvermittlung geschieht in der Kirche durch Christus im Heiligen Geist und die Gottesdienst feiernde Kirche wendet sich and den Vater durch Christus im Heiligen Geist" (R. Kaczynski, Das Wesen der Heilige Liturgie, [w:] Herders Theologischer Kommentar zum Zweiten Vatikanischen Konzil, t. 2, FreiburgBasel-Wien 2009, 71).

${ }^{73}$ KKK 1110: „In Ecclesiae liturgia, Deus Pater benedicitur et adoratur tamquam fons omnium benedictionum creationis et salutis, quibus Ipse nobis in Filio benedixit Suo, ad nobis Spiritum adoptionis filialis donandum". 
Syna $^{74}$ i w Duchu Świętym ${ }^{75}$ powraca do Ojca. Źródłowość Ojca została połączona z błogosławiącym charakterem liturgicznego wydarzenia: Ojciec, absolutne źródło liturgii, jest tym, który błogosławi. Liturgia jest uczestnictwem w błogosławieństwie Ojca. Uczestnictwo dokonuje się chrystologicznie i pneumatologicznie: wszystkie dary Ojca są rozdzielane w Synu i Duchu Świętym ${ }^{76}$. W tej perspektywie rola Syna w liturgii jest zasadniczo związana z pośredniczącym ${ }^{77}$ charakterem jego wcielenia i przebywania w świecie, którego szczytem jest paschalne wydarzenie ${ }^{78}$. Obecność Syna w liturgii i jego aktywne działanie umożliwione przez Ducha Świętego stanowi podstawę aktualizacji paschalnej tajemnicy zbawienia. W tej perspektywie liturgia zostaje ujęta - zgodnie $\mathrm{z}$ intuicją soboru - jako actio totus Christi ${ }^{79}$, to znaczy Chrystusa wraz z jego Kościołem $^{80}$. Działanie Ducha Świętego posiada istotnie chrystologiczną dynamikę: przygotowuje do przyjęcia Chrystusa (Spiritus Sanctus ad Christum praeparat accipiendum), upamiętnia jego tajemnicę (Spiritus Sanctus mysterium Christi in memoriam revocat) i czyni ją obecną (Spiritus Sanctus mysterium (hristi efficit actuale). Liturgiczne działanie Ducha Świętego nie ogranicza sięjednak jedynie do komunikowania tajemnicy

${ }^{74}$ KKK 1111: „Christi opus in liturgia est sacramentale quia Eius mysterium salutis per virtutem Spiritus Sancti Eius efficitur praesens; quia Eius corpus, quod est Ecclesia, veluti sacramentum (signum et instrumentum) est per quod Spiritus Sanctus mysterium salutis dispensat; quia Ecclesia peregrinans, per suas actiones liturgicas, iam praegustando, liturgiam participat caelestem".

${ }^{75}$ KKK 1112: „Spiritus Sancti missio in Ecclesiae liturgia est congregationem praeparare ut Christo occurrat; fidei congregationis Christum commemorare et praesentare; per Suam transformantem virtutem opus salvificum Christi praesens reddere et actuale atque efficere ut donum communionis in Ecclesia ferat fructus”.

${ }^{76}$ KKK 1082: „In Ecclesiae liturgia, benedictio divina plene revelatur et communicatur: Pater tamquam fons et finis omnium benedictionum creationis et salutis agnoscitur et adoratur; in Verbo Suo, pro nobis incarnato, mortuo et resuscitato, nos Suis cumulat benedictionibus, et per Illum in corda nostra donum effundit quod omnia continet dona: Spiritum Sanctum".

${ }_{77}$ Por. G. Wainwright, Doxology. The Praise of God in Worship, Doctine and Life. A Systematic Theology, Oxford 1980, 62-70.

${ }^{78}$ KKK 1085: „In Ecclesiae liturgia, Christus Suum Paschale mysterium praecipue significat et efficit".

${ }^{79}$ KKK 1136: „Liturgia «actio» est totius Christi. Illi qui nunc eam ultra signa celebrant, sunt iam in liturgia caelesti, ubi celebratio plene communio est et festum".

${ }^{80}$ KKK 1140: „Tota communitas, corpus Christi suo Capiti unitum, celebrat”. 
Chrystusa. Duch Święty jest nie tylko „żywą pamięcią Kościoła” (Spiritus Sanctus vivens Ecclesiae est memoria) o wydarzeniu i tajemnicy Chrystusa, lecz jest tym, który współdziała z Kościołem, karmiąc go nowym życiem zmartwychwstałego Pana ${ }^{81}$.

Streszczając katechizmowe intuicje, można stwierdzić, iż Ojciec jest źródłem liturgicznej działalności. To on jest „przedmiotem” całego kultu publicznego, którego głównym wykonawcą jest Chrystus Kapłan (Christi opus in liturgia), wcielony przedwieczny Syn. Liturgiczne dzieło Ducha Świętego to nade wszystko prowadzenie ku Chrystusowi.

Widać tu wyraźnie pozostałości schematu ontologii medioplatońskiej zbudowanej na relacji wyjścia (prodos) i powrotu (epistrofe) $)^{82}$. Zgodnie z założeniami tejże metafizyki cała rzeczywistość stworzona wykazuje wybitnie dynamiczny charakter. Jest ona nieustannym procesem wychodzenia i powrotu do absolutnej jedności (hen) twórczego początku. Schemat taki został dość wcześnie zaadoptowany i przekształcony na potrzeby ewangelizacji i jej teologii. Dynamika ruchu od początku do początku zostaje tu ujęta, zgodnie ze świadectwem Nowego Testamentu, trynitarnie. Początek stworzonej dynamiki wychodzenia i powracania stanowi absolutna zasada osobowa, jaką jest przedwieczny Ojciec. Jego przedwieczny i równy mu Syn w mocy Ducha jest medium reducens $s^{83}$ całego procesu. To dzięki niemu stworzenia morze zaistnieć i dzięki niemu może powrócić do Ojca. Redukująca moc (dynamis) Syna zakorzeniona jest zarówno w jego synowskiej relacji do Ojca jak i operatywnej obecności Ducha Świętego ${ }^{84}$.

Cała przedstawiona powyżej trynitarna teologia liturgii w duchu Vaticanum II opiera się na założeniu związku ekonomii i immanencji

${ }^{81}$ KKK 1091: „Spiritus Sanctus est in liturgia paedagogus fidei populi Dei, artifex «operum capitalium Dei» quae Novi Testamenti sunt sacramenta. Optatum et opus Spiritus in corde Ecclesiae est ut ex Christi resuscitati vivamus vita. Cum in nobis fidei invenit responsum quod Ipse suscitavit, vera fit cooperatio. Propter hanc liturgia opus fit commune Spiritus Sancti et Ecclesiae".

${ }^{82}$ G. Reale, Historia filozofii starożytnej, t. 4: Szkoły epoki cesarstwa, Lublin 1999, 345-368.

${ }^{83}$ Bonawentura, Hex., I, 10nn (V, 330nn).

${ }^{84}$ KKK 1104: „Liturgia christiana non solum commemorat eventus qui nos salvaverunt, sed eos actuales reddit, praesentes efficit. Paschale Christi mysterium celebratur, non iteratur; celebrationes iterantur; in unaquaque ex illis effusio supervenit Spiritus Sancti qui unicum mysterium reddit actuale". 
trynitarnej. Liturgia jest takiego związku wybitnym potwierdzeniem i pierwszym miejscem.

Kraków

KS. ROBERT WOŹNIAK

\section{Słowa kluczowe}

Teologia, liturgia, Trójca, Biblia, patrystyka, Sobór Watykański II

\section{Summary}

\section{Historical-systematic fundaments of the Trinitarian theory of the liturgical event}

The object of present research is to develop some fundamental traces of the Trinitarian understanding of the Christian liturgy. The article attempts to point out to the fundamental coordinates of Trinitarian comprehension of the liturgy from the historical perspective. In order to do this, it traces the links between first formulations of Trinitarian faith and early development of the Christian liturgy. The argument starts with consideration of some new biblical approaches to the phenomena of early Christian cult seen in its theological (Christological and Trinitarian) constellation (Bauckham, Hurtado). After this preliminary biblical-theological inquiry, some fundamental patristic texts are taken into account. The last stage of investigation is presentation of Second Vatican Council's account of the theology of liturgy which proofs itself to be openly Trinitarian.

\section{Keywords}

Theology, liturgy, Trinity, Bible, patristic, II Vatican Council 
